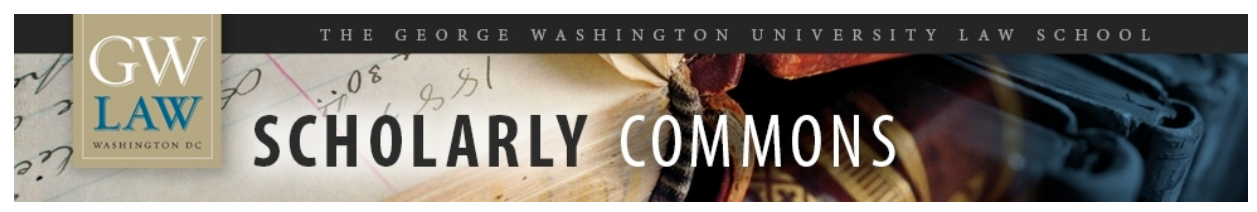

\title{
Formal Versus Functional Method in Comparative Constitutional Law
}

\section{Francesca Bignami}

George Washington University Law School, fbignami@law.gwu.edu

Follow this and additional works at: https://scholarship.law.gwu.edu/faculty_publications

Part of the Law Commons

\section{Recommended Citation}

Bignami, Francesca, Formal Versus Functional Method in Comparative Constitutional Law (2016). Bignami, Francesca. "Formal versus Functional Method in Comparative Constitutional Law." Osgoode Hall Law Journal 53.2 (2016) : 442-471.; GWU Law School Public Law Research Paper No. 2016-39; GWU Legal Studies Research Paper No. 2016-39. Available at SSRN: http://ssrn.com/abstract=2835721

This Article is brought to you for free and open access by the Faculty Scholarship at Scholarly Commons. It has been accepted for inclusion in GW Law Faculty Publications \& Other Works by an authorized administrator of Scholarly Commons. For more information, please contact spagel@law.gwu.edu. 


\title{
Formal versus Functional Method in Comparative Constitutional Law
}

\begin{abstract}
In the field of comparative constitutional law, the dominant approach to concept formation and research design is formal. That is, comparative projects generally identify what counts as the supreme law that can be enforced against all other sources of law based on the "constitutional" label of the positive law (written constitutions and the jurisprudence of constitutional courts) and the law books. This formal method, however, has significant limitations when compared with the functional method used in the field of comparative law more generally speaking. After a brief exposition of the functional method, this article explores the advantages of the functional method as applied to comparative constitutional law with the problem of judicial review (based on the supreme law) of social and economic policy-making in France, the United States, and Germany. Only in Germany is this law contained in constitutional law. In France, the supreme law is to be found largely in administrative law, because the constitutional court faces an institutional competitor, some would say superior, in the highest administrative court (Conseil d'État). In the United States, the supreme law is to be found in administrative law because economic and social rights- the rights that most directly affect this area of state activity—have largely been read out of constitutional law. Based on the functional method, the article proceeds to identify the similarities that unite the law of France and Germany and that set it apart from the law of the United States. It also outlines the important avenues of theoretical inquiry triggered by these similarities and differences in judicial review. The article concludes by sketching a functional agenda for empirical research in comparative constitutional law.
\end{abstract}

\section{Keywords}

Constitutional Law 


\title{
Formal versus Functional Method in Comparative Constitutional Law
}

\author{
FRANCESCA BIGNAMI*
}

In the field of comparative constitutional law, the dominant approach to concept formation and research design is formal. That is, comparative projects generally identify what counts as the supreme law that can be enforced against all other sources of law based on the "constitutional" label of the positive law (written constitutions and the jurisprudence of constitutional courts) and the law books. This formal method, however, has significant limitations when compared with the functional method used in the field of comparative law more generally speaking. After a brief exposition of the functional method, this article explores the advantages of the functional method as applied to comparative constitutional law with the problem of judicial review (based on the supreme law) of social and economic policymaking in France, the United States, and Germany. Only in Germany is this law contained in constitutional law. In France, the supreme law is to be found largely in administrative law, because the constitutional court faces an institutional competitor, some would say superior, in the highest administrative court (Conseil d'État). In the United States, the supreme law is to be found in administrative law because economic and social rights-the rights that most directly affect this area of state activity-have largely been read out of constitutional law. Based on the functional method, the article proceeds to identify the similarities that unite the law of France and Germany and that set it apart from the law of the United States. It also outlines the important avenues of theoretical inquiry triggered by these similarities and differences in judicial review. The article concludes by sketching a functional agenda for empirical research in comparative constitutional law.

Dans le domaine du droit constitutionnel comparé, une approche formelle est privilégiée en ce qui a trait à la formation conceptuelle et à la méthodologie de la recherche. Autrement dit, les projets comparés identifient généralement ce qui constitue la loi suprême, qui prévaut sur toutes les autres sources juridiques sur la base de l'étiquette « constitutionnelle » de droit positif (constitutions écrites et jurisprudence des tribunaux constitutionnels) et sur les livres de droit. Cette méthode formelle est toutefois frappée d'importantes limites en comparaison

* Professor of Law, George Washington University Law School. I am grateful to the two anonymous reviewers for their helpful comments. 
de la méthode fonctionnelle utilisèe plus généralement dans le domaine du droit comparé. Après avoir brièvement exposé la méthode fonctionnelle, cet article décrit ses avantages lorsqu'elle est appliquèe au droit constitutionnel comparé avec le problème du contrôle judiciaire (fondé sur la loi suprême) de formulation de politiques sociales et économiques en France, aux États-Unis et en France, aux États-Unis et en Allemagne. Seulement en Allemagne cette loi est-elle contenue dans le droit constitutionnel. En France, la loi suprême repose largement sur le droit administratif, du fait que la cour constitutionnelle y fait face à un concurrent institutionnel - que certains diront supérieur - formé par le plus haut lle Conseil d'État). Aux États-Unis, la loi suprême se trouve dans le droit administratif car les droits économiques et sociaux - droits qui affectent le plus directement ce domaine de l'activité de l'État - ont largement été tirés du droit constitutionnel. À partir de la méthode fonctionnelle, l'article identifie ensuite les similitudes qui rapprochent les droits français et allemand et qui les différencient du droit américain. Il souligne également les importantes avenues de questions théoriques soulevèes par ces similitudes et ces différences dans le controle judiciaire. L'article se termine en traçant un ordre du jour fonctionnel de recherche empirique en droit constitutionnel comparé.

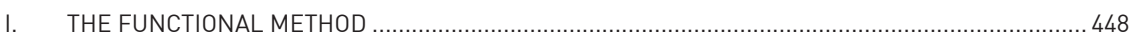

II. JUDICIAL REVIEW OF SOCIAL AND ECONOMIC POLICY-MAKING: AN ILLUSTRATION

OF THE FUNCTIONAL ADVANTAGE

A. The French Solution: Administrative Law and General Principles of Law........................ 456

B. The American Solution: Administrative Law and Proceduralized Rationality Review....... 459

C. The German Solution: Constitutional Law and Economic and Social Rights..................... 461

III. EMPIRICAL AND THEORETICAL PAYOFFS FROM THE FUNCTIONAL METHOD

IV. CONCLUSION: A FUNCTIONAL AGENDA FOR EMPIRICAL RESEARCH IN COMPARATIVE CONSTITUTIONAL LAW.

SINCE THE FALL OF THE BERLIN WALL, the field of comparative constitutional law has grown rapidly. ${ }^{1}$ At least part of the reason has been the spread of democratic constitutions and constitutional courts. ${ }^{2}$ With the rise of these two legal categories in over 150 countries across the world, the field now possesses the underlying similarity-the tertium comparationis-essential for most comparative studies. Today, in the vast majority of jurisdictions, it is possible to identify a supreme law, i.e., a written constitution, and a supreme constitutional

1. See Ran Hirschl, Comparative Matters: The Renaissance of Comparative Constitutional Law (Oxford: Oxford University Press, 2014).

2. In this article, "constitutional court" is used as shorthand for courts with the power to review the acts of public bodies based on the guarantees contained in the constitution. It refers both to systems of diffuse review and systems of concentrated review. 
court charged with enforcing that supreme law against all other public bodies. ${ }^{3}$ The same process of convergence that has made comparative research possible has also made it important. By definition, comparative constitutional law is research that addresses the supreme law of the land. It is also research with a natural and supreme audience, namely the constitutional courts that have been created throughout the world. For good reason, therefore, comparative constitutional law is a flourishing field of research. ${ }^{4}$

Although convergence on legal categories has been productive for the field of comparative constitutional law, it also has significant conceptual pitfalls. In comparative studies, deciding what to compare is critical. ${ }^{5}$ That initial decision drives the types of questions that can be asked, the theories that can be developed and tested, and the policy implications that can be derived for courts and other political and social actors. One of the major reasons for the success of the field of comparative constitutional law is that it is built around a common premise as to what deserves comparison, to repeat, written constitutions and constitutional

3. Even democracies that are known for the absence of a written constitution and constitutional review have today adopted human rights charters that have higher law status, albeit not enforceable through the same form of constitutional review as in the classic model. See Stephen Gardbaum, The New Commonwealth Model of Constitutionalism: Theory and Practice (Cambridge: Cambridge University Press, 2012).

4. There is now an impressive body of comparative work, using both small-N and increasingly large- $\mathrm{N}$ methodologies, which investigates the existence, content, and operation of constitutions across a wide array of historical and geographical settings. See e.g., Alec Stone Sweet, The Birth of Judicial Politics in France (New York: Oxford University Press, 1992); Sujit Choudhry, Constitutional Design for Divided Societies (New York: Oxford University Press, 2008); Mark Tushnet, Weak Courts, Strong Rights: Judicial Review and Social Welfare Rights in Comparative Constitutional Law (Princeton: Princeton University Press, 2008); Zachary Elkins \& Tom Ginsburg, The Endurance of National Constitutions (New York: Cambridge University Press, 2009); David Fontana, “Government by Opposition” (2010) 119:3 Yale LJ 548; Ran Hirschl, Constitutional Theocracy (Cambridge, Mass: Harvard University Press: 2010); Vicki C Jackson, Constitutional Engagement in a Transnational Era (New York: Oxford University Press 2010); David S Law \& Mila Versteeg, "The Evolution and Ideology of Global Constitutionalism" (2011) 99:5 Cal L Rev 1163; Michel Rosenfeld \& András Sajó eds, The Oxford Handbook of Comparative Constitutional Law (Oxford: Oxford University Press, 2012); Tom Ginsburg \& Rosalind Dixon, eds, Comparative Constitutional Law (Cheltenham, UK: Edward Elgar, 2013); Richard Albert, "Amending Constitutional Amendment Rules" (2015) 13:3 Int'l J Const L 655.

5. See Giovanni Sartori, "Comparing and Miscomparing” (1991) 3:3 J Theor Pol 243. 
courts. ${ }^{6}$ But it should also be recognized that using written constitutions and constitutional courts to identify the object of comparison is an extremely formal approach to concept formation and theory development. It is formal not because it investigates only black-letter law, but because it identifies what counts as the supreme law that can be enforced against all other sources of law based on the labels given in the positive law and the law books of the many jurisdictions being compared. If rules in one jurisdiction are found in a legal text called a "constitution" and a scholarly treatise on "constitutional law," then they can be compared with the rules in another jurisdiction that are also found in a "constitution" and a scholarly treatise on "constitutional law."

In this article I suggest that the formal method in comparative constitutional law has significant limitations. I do so by exploring the dominant method in the field of comparative law more generally speaking, namely an approach that identifies what law will be compared based on the functional social problems solved by the law. ${ }^{7}$ In comparative research that uses this so-called "functional method," the law that is compared is determined by reference to a social problem that is presumed to be similar across different jurisdictions. A social problem can be defined at a very low level of abstraction-for instance, when the police may stop and search an individual on the street—or a much higher level of abstraction-for instance, how to guarantee fair and effective policing. The object of comparison is whatever laws, and oftentimes whatever extra-legal forms of economic, social, and political organization, exist to address the social problem in the jurisdictions under investigation. Thus the law that is compared can use different doctrinal constructs, can be drawn from different legal sub-fields, or

6. The use of written constitutions and constitutional courts to identify the object of comparison corresponds with what is often called "big-C" constitutional law in the comparative literature. There is a developing literature on "small-c" constitutional law, based not on a written constitution but on common law or statutory law. This literature, however, is generally confined to single jurisdictions and is not comparative. See William N Eskridge, Jr \& John Ferejohn, "Superstatutes" (2001) 50:5 Duke LJ 1215; Bruce Ackerman, "The Living Constitution" (2007) 120:7 Harv L Rev 1738. Another subset of literature is aimed at developing the general concept of constitutions and constitutional law. See Stephen Gardbaum, "The Place of Constitutional Law in the Legal System" in Michel Rosenfel \& András Sajó, eds, Oxford Handbook of Comparative Constitutional Law (Oxford: Oxford University Press, 2012) 169. This article contributes to the literature on "big-C" and "small-c" constitutionalism by developing an analytical method for comparative research that can capture both types of constitutionalism, both within and across jurisdictions.

7. See generally Ralf Michaels, "The Functional Method of Comparative Law" in Mathias Reimann \& Reinhard Zimmerman, eds, The Oxford Handbook of Comparative Law (Oxford: Oxford University Press, 2006) 339. 
can, in some instances, not be law at all, but rather involve organizations, norms, and practices operating outside the law.

Applied to constitutional law, the functional method focuses on the supreme law governing the social problem at issue. It analyzes not just the written constitution and the stream of cases generated by constitutional courts, but also, depending on the jurisdiction, any other positive law and jurisprudence that operate as entrenched higher law. Since constitutional law has traditionally been concerned with public power, the social problems connected with the legitimate organization of public authority can be expected to be the most prevalent. Elections, political parties, the police, local authorities, the provision of basic services, and the operation of the political, administrative, and judicial branches are but some of the subjects—and supreme law—-that can be explored with a functional approach to comparative inquiry. In certain jurisdictions, however, constitutional law has even come to regulate the private sphere. Therefore, for purposes of certain research projects in comparative constitutional law, it might be appropriate to begin from a private law problem, such as the employment relationship or consumer contracts, to pinpoint the supreme law and to compare across jurisdictions.

The functional method of selecting the "what" of comparison has significant empirical and theoretical payoffs relative to the formal method currently employed in comparative constitutional law. The first relates to the hierarchical status of legal norms, in particular constitutional law, within a specific jurisdiction. The functional method does not assume that what appears to be a "constitution" and a "constitutional court" to an outsider, based largely on the law books, is indeed the supreme law and the supreme court of the land. While constitutions and constitutional courts might be the apex of the legal system, it is equally possible that they compete internally with other sources of law and judicial bodies. It might even be that the law as a whole is subordinate to other forms of social organization that are responsible for the lion's share of dispute resolution and norm generation. A comparative inquiry that begins from a particular social problem, rather than the formal status of the constitution as the highest source of law, is well equipped to capture this variation in the hierarchy of norms and dispute-resolution bodies across different legal systems.

The second advantage of the functional method relates to the substance of constitutional law. Constitutions and constitutional courts are generally thought to be interesting not merely because they are the last word but because they are the last word on topics such as free speech, privacy, the right to property, and the structure of public power. In other words, they are believed to set the 
ground rules for the entire universe of public law (and, in some systems, private law too). Yet, in fact, what they do and what they decide is highly variable among legal systems. Constitutions and constitutional courts can, for a variety of reasons, have relatively little to say on important areas of public law such as law enforcement, social and economic policy-making, and associational rights. They may have so little to say that, for all intents and purposes, the last word rests with an entirely different set of legal sources and judicial bodies. Again, the functional method, which looks to all branches of law, and sometimes outside the law, for the supreme rules and judicial bodies that govern the social problem at hand, is well placed to handle the inevitable variation in how legal categories have developed over time in different historical and national contexts.

As I will argue below, these two advantages are concretely illustrated by the example of legal oversight of social and economic policy-making, i.e., judicial review of complex statutory schemes involving issues such as the environment, consumer protection, and social insurance. While in Germany, constitutional law and the Constitutional Court play an important role in curtailing the activities of the state in this domain, in France and the United States most judicial review occurs under the guise of administrative law. This variation, which would be lost on a formal method that stuck to the four corners of "constitutional law," is captured by the functional method. In the case of France, this variation is captured thanks to the first advantage of the functional method-its flexible approach to the hierarchy of norms within legal systems. Due to the traditional republican suspicion of courts and constitutional review, constitutional law does not operate at the apex of the legal system in the domain of social and economic policy-making. The jurisdiction of the French Constitutional Council is relatively limited and access to judicial review has been primarily through the administrative courts, i.e., the Council of State (Conseil d'État). In the case of the United States, the second advantage of the functional method is in evidence-the ability to look beyond constitutional law when it is silent on the subject. Social and economic rights, which are the individual rights implicated most directly by this area of state activity, are largely absent from the jurisprudence of the United States Supreme Court, and it is therefore necessary to turn to administrative law to find the higher-law constraints on social and economic policy-making.

Whether these advantages of the functional approach are significant depends on the research question that motivates the comparative inquiry. For research in the domain of political philosophy, in which constitutions are believed to be expressions of political community, the terms of a written constitution as interpreted by a court are important in their own right for how they constitute 
the identity of that community. A functional method that looks to sources of law outside the written constitution may not be particularly relevant to such an inquiry. Research that is designed to instruct constitutional courts on how their counterparts in other countries interpret and apply similar constitutional provisions similarly may not benefit from the functional method. But for research that seeks to understand how the law affects politics and society, and how politics and society affect the law, it may be necessary to cast the net wider than is permitted by the formal method. The significant differences in how the law has evolved historically to enable and constrain power suggest that at least in certain substantive domains and in certain countries, it is necessary to consider a variety of legal bodies and sources to build robust theories of how the law develops over time and how it affects the dynamics of power and contestation within polities.

The remainder of this article is organized as follows. Part I briefly outlines the functional approach to comparative research, which was originally developed in the private law domain. Part II illustrates the use of the functional method in the area most directly implicated by constitutional law-the public law of state authority. It does so by comparing judicial review of social and economic policy-making in France, the United States, and Germany. Part III highlights the empirical and theoretical insights derived from the functional approach to comparative inquiry. Part IV concludes with suggestions for a functional research agenda for empirical projects in the field of comparative constitutional law.

\section{THE FUNCTIONAL METHOD}

Outside of constitutional law, the functional method is the dominant approach to research in the field of comparative law. The functional method was originally developed and has been applied mostly in the context of private law, i.e., the regulation of relations between private individuals through contract, tort, and other forms of law. Today, however, it can also be used productively in public law, i.e., the regulation of the state and the relations between private actors and the state, including constitutional law. With the gradual (although certainly not linear or universal) process of liberalization of markets and democratization of politics across a wide range of jurisdictions, public law faces a number of common problems that can be usefully explored through the functional method. The following section explains the origins and content of the functional method, explores debates over the method in the field of comparative law, and points to the potential for using the method in public law. 
The beginnings of the contemporary discipline of comparative law are generally traced to the first International Congress of Comparative Law held in $1900 .^{8}$ At the time, and still today, the field was dedicated to a number of purposes: understanding foreign legal systems; improving domestic legislation by looking to foreign examples; identifying and understanding legal traditions so as to comprehend similarities and differences among jurisdictions; and preparing the way for international efforts at law unification through systematic comparative analysis. ${ }^{9}$ A couple of decades later, and particularly with reference to comparative research directed at unification, a distinct approach to conducting comparative research emerged: the functional method.

The functional method is generally believed to have originated in the $1920 \mathrm{~s}$ in the thought and work of the great German comparatist Ernst Rabel. ${ }^{10}$ It was later formalized and popularized by a number of his successors in the German academy, among whom Konrad Zweigert and Hein Kötz are probably the most famous. ${ }^{11}$ According to the functional method, the law of different countries can be compared by locating a common social problem, rooted in the demands and needs of societies and expressed in terms abstracted from the intricacies of the law, and then identifying the various legal solutions to the problem in the different jurisdictions. These solutions might be found in the conventional sources of law, such as legislation, legal textbooks, and court judgments, but might also be furnished by social and institutional practices that arise outside of the law, such as the private insurance schemes that in some systems have evolved in place of the law. With the common social problem and the different legal solution, which was largely a product of national sovereignty and the historical and territorial specificity of the law, the functional method developed a stock

8. See generally Jürgen Basedow, "Comparative Law and its Clients" (2014) 62:4 Am J Comp L 821.

9. For purposes of this article, I used the term "law unification" broadly to refer to any attempt to harmonize the law across jurisdictions, whether through the legislative efforts of international bodies, the jurisprudence of international tribunals, or academic projects designed to inform directly or indirectly the work of international and domestic bodies.

10. See Michele Graziadei, "The Functionalist Heritage" in Pierre Legrand \& Roderick Munday, eds, Comparative Legal Studies: Traditions and Transitions (Cambridge: Cambridge University Press, 2011) 100.

11. See Konrad Zweigert \& Hein Kötz, Introduction to Comparative Law, 3rd ed, translated by Tony Weir (Oxford: Clarendon Press, 1998). 
approach to including both similarity and difference in defining the "what" of comparison, a necessary element of most comparative research. ${ }^{12}$

The functional method was not, however, directed at all forms of comparative inquiry, for any purpose. As mentioned above, it was developed largely in research directed at creating uniform law. Therefore, beyond defining the "what" of comparison, it also contained a number of additional analytical moves. Researchers were instructed that even if a legal solution in the system under investigation was not immediately apparent, they should nevertheless persist and continue to search across all areas of law and social and economic organization, since more often than not, a response to the problem would exist in one form or another. ${ }^{13}$ The various legal solutions were labelled as "functional equivalents," 14 i.e., although different in their legal particularities, they were all addressed to the same social problem. Well-known examples of functional equivalents that can be lost on legal scholars who hew too closely to domestic law books and formal categories of the law include tort law versus social insurance schemes in response to the common problem of motor vehicle accidents; ${ }^{15}$ the common law doctrine of consideration versus the civil law theory of causa as alternative solutions to the problem of the enforceability of contracts; ${ }^{16}$ and official land registries versus title insurance as ways of ascertaining ownership of real property. ${ }^{17}$ Once all the legal solutions were identified in the various jurisdictions, the similarities and differences could be compared. The functional method, again informed largely by the law-unification mission, predicted that the ultimate solution to the problem would be revealed to be the same even though the particulars of the law (or extra-legal arrangement) might be different. ${ }^{18}$ In other words, to continue with the same examples, most systems would probably opt to compensate victims of car accidents, to deny legal enforcement of bargains entered into without an arms-length transaction, and to protect buyers of land from third-party claims,

12. See Gerhard Dannemann, "Comparative Law: Study of Similarities or Differences?" in Mathias Reimann \& Reinhard Zimmerman, eds, The Oxford Handbook of Comparative Law (New York: Oxford University Press, 2006) 383. For an explanation of the importance of similarity and difference in the related discipline of comparative politics, see Sartori, supra note 5 at 246.

13. Zweigert \& Kotz, supra note 11 at 680.

14. Michaels, supra note 7 at 369.

15. Zweigert \& Kotz, supra note 11 at 680.

16. James Gordley \& Arthur Taylor von Mehren, An Introduction to the Comparative Study of Private Law: Readings, Cases Materials (New York: Cambridge University Press, 2006) at 421-22.

17. Zweigert \& Kotz, supra note 11 at 39 .

18. Dannemann, supra note 12 at 402 . 
even though they might do so through very different legal or extra-legal means. Based on this similarity revealed through comparison, it would be possible to reach agreement on a common set of rules, or in those instances of difference, it would be possible to evaluate the different solutions and come to an agreement on the best one. ${ }^{19}$

Somewhat later, the functional method also became associated with another feature of research design, again driven by the law-unification ends of comparative research. Beginning with Rudolf Schlesinger's Cornell project on the formation of contracts, many collective projects on specific areas of law have taken as their starting point highly fact-specific characterizations of the social problem, which then define the scope of the "what law" being compared. ${ }^{20}$ The prime example is the Common Core of European Private Law project, a long-running academic initiative to investigate issues of comparative private law in European jurisdictions. ${ }^{21}$

The factual approach can be illustrated with the first publication to result from the Common Core project. This publication focused on the issue of good faith in European contract law. ${ }^{22}$ The springboard for the research was a series of fact hypotheticals, which led to a series of national reports on how such facts were handled in the different jurisdictions. These reports in turn served as the basis of the general report that sought to summarize and analyze the many points of convergence and divergence revealed by the national reports. ${ }^{23}$ The social problems used by the national reporters to identify the relevant law were all fact hypotheticals like the following:

Desdemona is a dealer in fine art and sees what she considers to be a rare and valuable drawing at the house of Othello, a retired physics professor who has asked her to look at his possessions with a view to purchase. Desdemona asks him about the drawing and he tells her that he knows that it is old and that he has always liked it, but has no idea of its value. Desdemona offers him $£ 1,200$ which he accepts. The picture is later authenticated by art experts and Desdemona resells it for $£ 85,000 .{ }^{24}$

19. Jonathan Hill, “Comparative Law, Law Reform and Legal Theory" (1989) 9:1 Oxford J Legal Stud 101 at 102-07.

20. Rudolf Schlesinger, ed, Formation of Contracts: A Study of the Common Core of Legal Systems (Dobbs Ferry, NY: Oceana Publications, 1968); Mauro Bussani \& Ugo Mattei, "The Common Core Approach to European Private Law” (1997-98) 3:3 Colum J Eur L 339.

21. Ibid.

22. Reinhard Zimmermann \& Simon Whittaker, eds, Good Faith in European Contract Law (Cambridge: Cambridge University Press, 2000).

23. Simon Whittaker \& Reinhard Zimmermann, "Coming to Terms with Good Faith" in Zimmermann \& Whittaker, supra note 22, 653.

24. Ibid at 208 . 
The national reports responding to this hypothetical indicated that the vast majority of countries reached the common solution of allowing Othello to rescind the contract with Desdemona. ${ }^{25}$ They did so, however, based on a variety of doctrinal grounds, each of which focused on a slightly different element of the relationship that warranted undoing the sales contract. ${ }^{26}$

Although (or perhaps because) the functional method is the most common approach to comparative legal research, it has generated a lively debate in the field of comparative law. Criticism of the method generally falls into two camps. First, the functional method is said to over-emphasize similarity and to ignore context and cultural particularity. ${ }^{27}$ There is some truth to this observation, but the emphasis on similarity is largely a by-product of the law-unification purpose to which much research in the functional tradition has been directed, rather than an intrinsic element of the method itself. The use of highly specific fact scenarios, the admonition that a social problem will generally trigger a legal or extra-legal response if only the researcher looks hard enough, and the working hypothesis that the solution to the social problem is more likely than not to be similar, are all characteristics of functional research in support of law unification. For researchers committed to building an international body of rules, it is politically far easier to make the case for such rules if they are portrayed as reflecting commonalities among the participating jurisdictions. There are, however, other purposes of comparative research, such as acquiring knowledge of foreign jurisdictions, developing taxonomies of world legal systems, understanding and reforming one's own national law, ${ }^{28}$ and building social scientific theories of law and courts. ${ }^{29}$ For these other purposes, it may very well be appropriate to define the social problem in more abstract terms, thus presuming less similarity in the daily conduct and legal needs of human interactions across different societies. What is more, when it comes time to assess the responses triggered by the common problem, it is certainly not necessary to assume that there will always be a response, or that the ultimate solution will be roughly similar. ${ }^{30}$ Difference and variation are desirable

25. Ibid at 233.

26. Ibid at 233-35.

27. See e.g. Hill, supra note 19; Pierre Legrand, "Variations on the Main Theme" in Pierre Legrand, ed, Fragments on Law-as-Culture (Deventer, Netherlands: WEJ Tjeenk Willink, 1999) 27.

28. H Patrick Glenn, "The Aims of Comparative Law" in Jan M Smits, ed, Elgar Encyclopedia of Comparative Law, 2d ed (Cheltenham, UK: Edward Elgar, 2012) 65.

29. See e.g. Martin Shapiro, Courts: A Comparative and Political Analysis (Chicago: The University of Chicago Press, 1981).

30. Dannemann, supra note 12 at 403-16. 
for many types of comparative projects, including mapping world legal systems, finding foreign inspiration for domestic law reform, and testing causal hypotheses on the development of legal institutions.

The second criticism of the functional method is that it focuses on the formal rules of the law rather than their actual operation in society. ${ }^{31}$ While again there is some truth to this "black-letter" claim, it is not a universal or necessary characteristic of the functional method ${ }^{32}$ To begin with, it is important to note that the functional method is far less black letter than the formal method of comparative constitutional law that currently dominates the field. Rather than looking to the law books of a particular branch of law to identify the law being studied, the functional method ranges far more broadly. Based on the social problem at issue, the researcher is tasked with independently identifying the important rules and dispute resolution bodies that exist within a society to address the problem, regardless of the label of the law book or indeed whether the rules are contained in the law books at all. More broadly, there is nothing to stop comparative researchers from investigating the origins and effects of the legal rules identified by means of the functional method. In fact, the comparative legal variation that is often revealed through the functional method can provide the ideal material for testing theories on the origins and effects of the law. In sum, the functional method can be sensitive to difference and similarity, can be used in studies focused on the socio-legal, not doctrinal, dimension of law, and can serve as a springboard for deploying a variety of qualitative and quantitative methodologies. ${ }^{33}$

So far, this article's discussion of the functional method has referred almost exclusively to private law. The reason for this is that the field of comparative law has traditionally had a bias towards private law. The degree of assimilation of legal systems necessary to render comparative law informative, especially for practical purposes, has historically existed more in the realm of the legal regulation of private relations among individuals than in the law that disciplines and shapes

31. See generally Matthias Reimann, "The Progress and Failure of Comparative Law in the Second Half of the Twentieth Century" (2002) 50:4 Am J Comp L 671 (reviewing different criticisms of comparative law).

32. See Basedow, supra note 8 at 840-57.

33. John Bell discusses a similar argument in favour of the functional method. See John Bell, "Comparative Law and Legal Theory" in Werner Krawietz, Neil MacCormak \& Georg Henrik von Wright, eds, Prescriptive Formality and Normative Rationality in Modern Legal Systems (Berlin: Duncker \& Humbolt, 1994) 19. 
the power of the state. ${ }^{34}$ To use the language of functionalism, the problems of commerce, property, and other areas of private law were, in the past, believed to be more universal than the problem of how to organize and exercise the legitimate authority of the state..$^{35}$ While there were many commonly perceived problems of private law (for instance, the enforcement of contracts) where comparative research could help shed light on domestic litigation and law-making or international unification, such common problems were much rarer in public law, where deep-rooted differences in political economy, institutional configurations, and political ideologies undermined the usefulness of comparative inquiry.

Today, however, as demonstrated by the vibrancy of the field of comparative constitutional law, public law presents at least as many opportunities for comparison as does private law. The demise of many of the underlying differences in public law that previously operated as a deterrent to comparative work can be attributed in part to the global diffusion of democracy following the fall of the Berlin Wall and the collapse of the great ideological divide between East and West. ${ }^{36}$ Although written constitutions and constitutional courts are perhaps one of the most visible legal components of democratization, the emergence of democracy as a common (although certainly not a universal or a universally established) organizing principle for public power implicates virtually every area of state activity and every aspect of law.

At roughly the same time, another important form of convergence occurred in the public law arena: convergence on the form and extent of state intervention in markets. In a number of jurisdictions, markets were privatized and liberalized, and state enterprise and industrial planning were curtailed and replaced with government regulation-the use of rules to set down the terms of competition for private market actors and to achieve a variety of social and redistributive purposes. ${ }^{37}$ As with the spread of democracy, the result is that the number of common problems susceptible to comparative investigation

34. See John Bell, "Comparing Public Law” in Andrew Harding \& Esin Örücü, eds, Comparative Law in the 21st Century (The Hague: Kluwer Law International, 2002) 235.

35. Ibid.

36. See generally Beth A Simmons, Frank Dobbin \& Geoffrey Garett, eds, The Global Diffusion of Markets and Democracy (Cambridge: Cambridge University Press, 2008).

37. Ezra N Suleiman \& John Waterbury, eds, The Political Economy of Public Sector Reform and Privatisation (Boulder, Colo: Westview Press, 1990); David Levi-Faur, "The Global Diffusion of Regulatory Capitalism" (2005) 598:1 Annals Am Ac Pol \& Soc Sci 12; Colin Scott, "Privatization and Regulatory Regimes" in Michael Moran, Martin Rein \& Robert E Goodin, eds, The Oxford Handbook of Public Policy (Oxford: Oxford University Press, 2006) 651; Mark Thatcher, Internationalisation and Economic Institutions: Comparing European Experiences (Oxford: Oxford University Press, 2007). 
has grown substantially. In sum, the possibilities for comparative work in the public law arena, including the highest law of interest to constitutional scholars, have multiplied exponentially over the past decades, and so too the potential applications of the functional approach to comparative inquiry.

\section{JUDICIAL REVIEW OF SOCIAL AND ECONOMIC POLICY- MAKING: AN ILLUSTRATION OF THE FUNCTIONAL ADVANTAGE}

Social and economic policy-making is characterized by a high level of complexity that requires, in addition to the standard tripartite branches of government, dedicated administrative authorities staffed by specialized public officials. Examples include statutory schemes designed to protect consumer safety and the environment, as well as those directed specifically at redistribution, such as universal health care and social security programs. For purposes of comparative research, the common social problem can be formulated as the task of regulating effectively, conceived sequentially from the formulation of rules to their application, and doing so in accordance with public values of democratic accountability and fundamental rights. ${ }^{38}$ At the core of this area of law is both a set of government activities involved in regulating market and society, and a set of normative standards as to how those activities are to be conducted, rooted in the theory and practice of liberal democracy. At each stage, different values are likely to be more prominent in the law. For instance, the law governing how the rules are made is likely to stress public accountability, while the law on rule application is likely to be more focused on efficiency and fairness. This difference rests on the classic distinction in liberal constitutional theory between rule-making and adjudication: Since rule-making sets down the rights and duties of broad classes of individuals, government should be accountable to democratic actors, but since adjudication applies those rules to specific individuals, the state should decide accurately, efficiently, and in compliance with individual due process. ${ }^{39}$

The functional problem, and the corresponding law covered by the comparative inquiry, can also be formulated at a lower and more analytically

38. Cf Francesca Bignami, "Introduction" in Francesca Bignami \& David Zaring, eds, Comparative Law and Regulation: Understanding the Global Regulatory Process (Cheltenham, UK: Edward Elgar, 2016) [forthcoming].

39. See Londoner v Denver, 201 US 373, 28 S Ct 708 (1908); Bi-metallic Investment Co v State Board of Equalization, 239 US 441, 36 S Ct 141 (1915). 
tractable level of specificity. The "what" of the comparative research can focus on one stage of social and economic policy-making-setting down the rules that govern markets and society-and on one prominent element of liberal democracy-judicial review in the courts. The researcher can then ask: What is the legal solution to the problem in different jurisdictions, and of particular interest for constitutional scholars, what is the supreme law on the matter? One can further inquire on what grounds, and more specifically, on what supreme-law grounds, can individuals challenge and will courts strike down social and economic policy decided by the political and administrative branches?

For purposes of this intellectual exercise, I cover three countries that are generally considered to be important in the literature: France, the United States, and Germany. As I explain below, the formal method, focused exclusively on constitutions and constitutional courts, captures only the German case and misses the vast majority of supreme law that curbs the policy-making activities of the contemporary state in France and the United States. The functional method, by contrast, casts a much wider net that includes the rules and principles in both the administrative and constitutional law books, and exposes the supreme law of social and economic policy-making in all three jurisdictions.

\section{A. THE FRENCH SOLUTION: ADMINISTRATIVE LAW AND GENERAL PRINCIPLES OF LAW}

In France, government policy-making can be challenged in both the administrative courts and the constitutional court. Due to the historically limited powers of the Constitutional Council, however, most challenges have traditionally been brought before the administrative courts. ${ }^{40}$ Even today, with the expanded jurisdiction of the Constitutional Council, the bulk of litigation continues to be heard by the administrative courts, in particular the highest court in the system, the Council of State (Conseil d'État) the Council of State, which generally has original jurisdiction over challenges to broadly applicable rules. ${ }^{41}$ The decisions of the Council of State are not reviewable by any other court, including the Constitutional Council. Before the Council of State, standing is quite liberal and is based on an "objective" theory of the function of the court: Litigation against

40. See generally John Bell, French Legal Culture (London: Butterworths, 2001) (discussing different branches of French law, including differences between Council of State and Constitutional Council).

41. In 2008, the Constitutional Council was given the power to review constitutional questions referred by the highest administrative and civil courts. See Alec Stone Sweet, "The Constitutional Council and the Transformation of the Republic" (2008) 25 C du Cons Const 65. 
the state is conceived as vindicating an objective interest in a republican system of government faithful to the rule of law rather than subjective rights in property and liberty, and therefore, in deciding whether to take a case, the main standing requirement is that there be an alleged violation of law. ${ }^{42}$ The review power of the Council of State applies only to government policy-making contained in regulatory acts, not statutes (lois), but most social and economic policy requires administrative action and will therefore be reviewed in one form or another by the Council of State. Moreover, in contrast with many other jurisdictions, the executive branch is empowered by Article 37 of the Constitution to enact norms (décrets autonomes) on all subjects not specifically attributed to the Parliament, and according to the jurisprudence of the Council of State, these norms are also subject to administrative law review. ${ }^{43}$ Therefore, in the policy-making domain, the powers of the Council of State and the scope of administrative law are quite broad.

Turning to the substance of the law applied by the Council of State to government policy-making, most of it falls within the classic conception of administrative law as an instrument for ensuring that administrative authorities act within the limits of the powers conferred upon them by the legislature. The grounds for challenging government acts generally come under the heading of excess of power (excès de pouvoir), which requires testing the relationship between the government act and the enabling legislation, and which operates as a rough equivalent to the common law doctrine of ultra vires government action. The Council of State, however, has also developed an extensive set of general principles of law (principes généraux $d u d r o i t$ ). These are higher law principles rooted in political theories of liberalism and republicanism and most are familiar from the fundamental rights protected in constitutions. ${ }^{44}$

Perhaps the most distinctive, and certainly one of the oldest, is the right to equality, which was first recognized by the Council of State in 1913 in the Roubeau case. ${ }^{45}$ It applies to both regulation and individual decision making,

42. For a discussion of the system and substance of administrative litigation in France, see $\mathrm{L}$ Neville Brown, John S Bell \& Jean-Michel Galabert, French Administrative Law, 5th ed (New York: Oxford University Press, 1998); Michel Fromont, Droit administratif des États européens (Paris: Presses Universitaire de France, 2007).

43. Étienne Picard, "Delegation of Legislative Power in French Public Law" in Mads Andenas \& Alexander Türk, eds, Delegated Legislation and the Role of Committees in the EC (The Hague: Kluwer Law International, 2000) 67.

44. Mitchel de S-O-l'E Lasser, Judicial Transformations: The Rights Revolution in the Courts of Europe (New York: Oxford University Press) at 232-33.

45. CE, 9 May 1913, (1913) Rec 521 [Roubeau]. 
and has evolved into a series of specific principles applicable to certain types of government activity: equality in the operation of public services; equality in taxation; equality in bearing public burdens (charges publiques); equal access to the civil service; equality between members of the civil service; sex equality; equality between nationals and non-nationals in the domain of fundamental rights; equality between users of public services or state-owned property (domaine public); and equal treatment under economic regulation. The principle is generally formulated as the duty to treat equal situations equally and different situations differently and requires that any difference in treatment be justified in light of the objectives of the enabling law. ${ }^{46}$ As is clear from the specific equality rights listed above, the categories that must be afforded equal treatment relate not only to national origin and sex but also to types of economic activity, recipients of public services, and the economic burdens of regulatory schemes. In other words, when reviewing government policies, the Council of State safeguards those fundamental rights that are most directly implicated by market regulation and social assistance programs.

It bears mentioning that both review for excess of power and respect for general principles of law are so deeply rooted in doctrine and legal culture that they are as entrenched in French law as any provision of the French Constitution. It is virtually impossible to conceive of any circumstances in which a democratic legislature would, or could, legislate away these rules and principles of permissible state action. Judicial review for excess of power and judicial review to uphold general principles of law are closely intertwined with the rule of law, democracy, and republican government, all of which are specifically recognized in the French Constitution. Even more important for understanding the supreme status of these rules in French law is the institutional stature of the Council of State within the French system of government. Any legislative proposal to do away with the principles established in the jurisprudence of the Council of State would flounder long before the proposal could come to a vote in the legislative assembly.

If we also include the advisory functions (and not just the adjudicatory functions) of the Council of State, it takes on an even more important role in ensuring legality and general principles of law in French policy-making (although the advisory functions are not, strictly speaking, a legal solution to the functional problem of judicial review of social and economic policy-making)..$^{47}$ All proposed legislation and most draft rules are sent to the legislative section of the Council

46. See Fromont, supra note 42 at 254.

47. See John Bell, Judiciaries Within Europe (Cambridge: Cambridge University Press, 2006) at $77-79$. 
of State, which is organized into a number of sub-sections by subject area. A rapporteur is assigned to the proposal. He or she holds meetings with the civil servants in the ministries who wrote the proposed legislation or rule; assesses whether the proposal is in line with other law in the area, the Constitution, and treaties; and drafts a new text of the law or rule, independent of the government's proposal. The section as a whole then compares the government's version and the rapporteur's version and decides which to follow. In the case of draft legislation, if the section follows the rapporteur, the government is free to accept or reject the new version and adopt its original bill. In most cases, the government adopts a mix of the two versions, taking some parts from the original version, others from the Council of State's version, and submitting a hybrid version to Parliament. As for rules that implement laws, depending on the terms of the enabling statute, the government may very well be required to adopt the changes made by the Council of State.

\section{B. THE AMERICAN SOLUTION: ADMINISTRATIVE LAW AND PROCEDURALIZED RATIONALITY REVIEW}

In the United States, too, administrative rather than constitutional law is, functionally speaking, the highest law on the subject of social and economic policy-making. In contrast with France, the reason for the silence of constitutional law in this respect is not the difficulty of obtaining judicial review on constitutional grounds but the failure of the substance of constitutional law to discipline significantly the complex regulatory statutes of the modern administrative state. Structural guarantees such as the prohibition on conferring legislative powers on administrative agencies (the so-called "non-delegation" doctrine) have been applied so permissively as to allow most regulatory programs. ${ }^{48}$ At the same time, the individual rights most directly implicated by market-regulating and entitlement-conferring programs-social and economic rights-are afforded almost no constitutional protection. This is a product of the rigid hierarchy of fundamental rights that is distinctive to the American system and that has been amply documented in scholarship on comparative constitutional law. ${ }^{49}$ Economic rights and classifications belong to the lowest tier of the hierarchy,

48. See Cass R Sunstein \& Adrian Vermeule, "Libertarian Administrative Law” (2015) 82:1 U Chicago L Rev 393 at 417-23.

49. See Jud Mathews \& Alec Stone Sweet, "All Things in Proportion? American Rights Review and the Problem of Balancing" (2011) 60:4 Emory LJ 797; Aharon Barak, Proportionality: Constitutional Rights and Their Limitations, translated by Doron Kalir (Cambridge: Cambridge University Press, 2012) at 509-27. 
which is afforded only minimal, so-called "rational basis" judicial review. Most commentators agree that once a case is slotted into the "rational basis" category, the outcome in favour of the state and against individual rights is a foregone conclusion. ${ }^{50}$ As for social rights, the US Supreme Court, in contrast with other constitutional courts, has tended to define the scope of rights narrowly and to refrain from creatively interpreting constitutional text to recognize new rights. ${ }^{51}$ This has had an impact especially in the domain of the welfare state: The US Supreme Court has not recognized any positive socioeconomic rights as constitutional rights, and there are few judge-made constraints on drastic shifts in entitlement programs, either at the legislative or the administrative levels. ${ }^{52}$

As a result of this doctrinal history, most of the supreme law on social and economic policy-making comes under the heading of administrative law. It is directed against the rules and other policy instruments used by administrative agencies to implement legislative programs (which, to repeat, are almost without exception necessary in the case of social and economic policy) and is based on statutory law or common law principles developed by the courts. The most foundational of those statutes, the Administrative Procedure Act, ${ }^{53}$ together with the common law overlay that has developed since its adoption, have been recognized by many legal scholars to be so entrenched as to approximate constitutional law. ${ }^{54}$ Similar to most other systems committed to the rule of law, judicial review seeks to guarantee that administrative agencies remain within the scope of power delegated in the enabling legislation. What is distinctive about American judicial review is what one leading administrative law scholar has labeled "proceduralized rationality review." ${ }^{5}$ Proceduralized rationality review encompasses a number of doctrinal grounds of review, including the procedural requirements of notice-and comment rule-making, and the substantive standard of "arbitrary and capricious" review, which was originally designed to capture instances of irrational agency action but evolved in the early 1970s into a highly demanding test, known

50. See Cass R Sunstein, "Interest Groups in American Public Law" (1986) 38:1 Stan L Rev 29.

51. See David P Currie, "Lochner Abroad: Substantive Due Process and Equal Protection in the Federal Republic of Germany" (1989) 1989 Sup Ct Rev 333.

52. See Francesca Bignami \& Carla Spivack, "Social and Economic Rights as Fundamental Rights” (2014) 62:4 (supp) Am J Comp L 561.

53. 5 USC $\$ 551$ (1946).

54. See e.g. David S Law \& Mila Versteeg, "Sham Constitutions" (2013) 101:4 Cal L Rev 863 at $872-73$.

55. Jerry L Mashaw, Creating the Administrative Constitution: The Lost One Hundred Years of American Administrative Law (New Haven: Yale University Press, 2012) at 289. 
today as "hard-look review." ${ }^{56}$ The result is that administrative agencies must demonstrate before the courts that at the time the policy choice was made, all of the available legal and policy options were considered and their relative advantages and disadvantages were assessed thoroughly in light of the underlying goals of the regulatory scheme.

\section{THE GERMAN SOLUTION: CONSTITUTIONAL LAW AND ECONOMIC AND SOCIAL RIGHTS}

In Germany, unlike in the United States and France, constitutional law predominates over administrative law in the domain of judicial review of social and economic policy-making. In other words, it is the only country in this comparative study in which the formal and functional definitions of constitutional law are indeed one and the same. The reasons for the prevalence of constitutional law over administrative law can be found in the jurisdictional attributes of the Federal Constitutional Court and the substantive guarantees of the Basic Law, as elaborated by the Constitutional Court. ${ }^{57}$ Through the system of constitutional complaints, it is relatively easy to obtain access to the Constitutional Court. ${ }^{58}$ Moreover, the Constitutional Court has jurisdiction over challenges to all types of government action, including all implementing regulations, unlike the French Constitutional Council, which only has jurisdiction over challenges to parliamentary laws. Finally, individual constitutional complaints can sometimes be used as the remedy of first, not last, resort, since there is no need to exhaust other remedies before filing with the Constitutional Court if there is a risk of serious and irreversible harm..$^{59}$

Coupled with the generous system of access to the Constitutional Court is a relatively strict set of constitutional guarantees in the area of social and economic policy-making. In line with the separation of powers and rule of law principles familiar in all three systems, when the legislature creates an administrative scheme that entails extensive executive powers in the form of regulations and other types of action, it is required to specify the "content, purpose, and scope of the authority conferred." ${ }^{60}$ Somewhat less familiar to American constitutional thinking but in

56. Stephen G Breyer et al, Administrative Law and Regulatory Policy: Problems, Text, and Cases, 7th ed (New York: Aspen, 2006).

57. See Donald P Kommers \& Russell A Miller, The Constitutional Jurisprudence of the Federal Republic of Germany, 3rd ed (Durham, NC: Duke University Press, 2012).

58. Ibid at 11-12.

59. Mauro Cappelletti, "Fundamental Guarantees of the Parties in Civil Litigation: Comparative Constitutional, International, and Social Trends” (1973) 25:5 Stan L Rev 651 at 660-61.

60. Kommers \& Millerat, supra note 57 at 175. 
line with European fundamental rights law, the duty to legislate in some detail is also designed to protect basic rights and to satisfy the requirement that any interference with rights be authorized by law. Although the American analogue, the non-delegation doctrine, has been criticized as toothless, some commentators have argued that in the German context, the Constitutional Court has been fairly strict in enforcing the duty. ${ }^{61}$ Of even more importance for the purpose of this discussion is the fact that some of the basic rights that the duty is designed to protect cut directly into social and economic policy-making. In particular, these are the freedom to choose and exercise a trade or profession (Article 12); freedom of commerce, contract, and industry flowing from the general right of personality (Article 2); and the guarantee of equality as applied to social and economic categories (Article 3). ${ }^{62}$ More recently, in the Hartz IV case, the Constitutional Court has suggested that there exists a positive socioeconomic right, derived from the principle of human dignity, to a basic level of subsistence. ${ }^{63}$

When these rights (as all other constitutional rights) are implicated, the legislature is under a special duty to legislate precisely. In addition, the authorizing legislation and any administrative action taken pursuant to discretionary powers lawfully conferred in the enabling law are subject to the well-known proportionality test (suitability, necessity, and balancing). ${ }^{64}$ This proportionality element of constitutional review is perhaps the most significant aspect of judicial review of social and economic policy-making.

The combined effect of the German system of constitutional adjudication and the substantive guarantees afforded under the German Basic Law is that most social and economic programs are vulnerable to challenges under constitutional law. Those challenges, moreover, often take the shape of paradigmatic constitutional litigation: a challenge based on the supreme law of the constitution and brought in the Constitutional Court against parliamentary law, not against administrative action. The legislature can generally be faulted either with not having legislated specifically enough, or with having legislated in a way that breaches one of the many economic and social rights protected by the Basic Law. For litigants, who often have a choice between challenging the law and challenging the rule adopted pursuant to the law, the strategic incentive is to attack the law first and

61. Ibid at 175,185 .

62. Grundgesetz der Bundesrepublik Deutschland, Arts 2, 3, 12. For an English translation, see

"Basic Law for the Federal Republic of Germany" Deutscher Bundestag (23 May 1949), online: <https://www.btg-bestellservice.de/pdf/80201000.pdf>.

63. BVerfGE, 125, 175 (9 February 2010).

64. See e.g. Barak, supra note 49. 
foremost. Why? Because an implementing regulation can be re-promulgated by the government with relative ease, but re-writing parliamentary law requires overcoming all the hurdles of the legislative process.

Three examples, drawn from the right to occupational freedom and the associated proportionality principle, will illustrate how constitutional law cuts into social and economic policy-making. In a challenge brought by a candy manufacturer to a federal regulation banning the sale of cocoa-like products because of the risk to consumers of confusing such sweets with real chocolate, the Constitutional Court found that the necessity prong had been violated because of the availability of a less-restrictive measure (a labelling requirement) to prevent consumer confusion. ${ }^{65}$ In another case, occupational freedom lost out to animal welfare. ${ }^{66}$ The Constitutional Court found that a farming regulation prescribing the minimum dimension of chicken coops was too favourable to farmer rights and did not adequately guarantee the animal welfare interests protected under the enabling statute. More recently, based on the same right of occupational freedom, the Constitutional Court struck down a law banning smoking in public restaurants because of the failure of the statutory scheme to consistently promote the purported aim of protecting against smoke. ${ }^{67}$

Constitutional law is not, of course, the only area of law relevant to social and economic policy-making in Germany. Administrative law is also important. It is, however, largely limited to the classic function, familiar from the preceding survey of administrative law in France and the United States, of guaranteeing that administrative action remain within the scope of delegated authority. The inquiry is focused on the legal definition of administrative powers and whether administrative action adheres to those powers, the factual and policy basis for the administrative determination, and the procedures followed by the administrative agency. ${ }^{68}$ When assessing the factual and policy basis for a determination, judicial review is informed by fairly robust principles of deference to administrative actors, known, depending on the context, as "administrative discretion" (Ermessen) and "margin of appreciation" (Beurteilungsspielraum). In addition, similar to French administrative law but different from American administrative law, procedural guarantees are generally vigorous in cases of individualized determinations, which raise due process concerns, but not in rule-making activities of a general nature.

65. BVerfGE, 53, 135 (16 January 1980).

66. BVerfGE, 101, 1 (13 April 1999).

67. BVerfGE, 121, 317 (11 June 2008).

68. See Mahendra P Singh, German Administrative Law in Common Law Perspective (Berlin: Springer, 2001). 
Thus, while administrative law is generally a significant limit on administrative action, it is much less so with respect to the subject matter and the functional problem at the core of this comparative analysis. In Germany, when the state actors set down the generally applicable rules that govern markets and social welfare schemes, the most significant source of legal constraint and individual rights is to be found not in administrative law, but in constitutional law.

\section{EMPIRICAL AND THEORETICAL PAYOFFS FROM THE FUNCTIONAL METHOD}

Although constitutional law, formally speaking the highest law that applies to public actors, might appear to be the natural starting point for a comparative study of social and economic policy-making, the analysis in the previous section demonstrates the advantages of the functional alternative. By casting a wider net, the functional approach is more successful at identifying the supreme law. In some countries, namely Germany, the law does indeed fall squarely under the label of constitutional law. In others, however, it comes under the heading of administrative law. In the French case, the relative unimportance of constitutional law is a reflection of a republican system in which judicial review by the constitutional court, based on the constitution, is not as firmly entrenched as other forms of legal oversight of public bodies. To put the point somewhat differently, in the French legal system, constitutional law is not supreme but is paralleled by other judicial hierarchies and sources of law that discipline the exercise of state power, namely the Council of State and administrative law. By contrast, in the American case, constitutional law plays second fiddle to administrative law not because of the unsettled status of constitutional law compared to other types of law (the United States is, after all, the land of Marbury v Madison ${ }^{69}$ ), but because the constitution has been interpreted to have relatively little to say on the subject of social and economic policy-making.

By providing a framework for capturing the law in different jurisdictions, the functional method also improves our empirical observation of the differences and similarities that mark various legal systems. As I have begun to show elsewhere, judicial review of social and economic policy-making in France and Germany, together with Europe more broadly, is focused on safeguarding rights, while American judicial review is rooted in a procedural vision of the administrative

69. 5 US (1 Cranch) 137, 2 L Ed 60 (1803). 
state. ${ }^{70}$ Even though, formally speaking, Germany is distinguished by the prominence of constitutional law while France and the United States share a reliance on administrative law, an examination of the content of the law suggests that France and Germany have a lot more in common with one another than with the United States. As explained in the previous section, aside from the classic administrative law concern of ensuring administrative fidelity to statutory commands, judicial review in both Germany and France is largely focused on safeguarding fundamental rights. The fact that in Germany, the source for the rights is the Constitution and the Constitutional Court, while in France it is the Council of State's jurisprudence on general principles of law, does not make much of a difference in light of the authoritative status of both courts in their respective systems of public law. True, there is one respect in which the constitutional as opposed to the administrative source of fundamental rights does make a difference in theory: the application of rights to parliamentary law. Even on this score, however, the practice and outcomes of judicial review based on rights may not be significantly different since the Council of State, as most courts, seeks to interpret statutes in conformity with fundamental rights. The difference is even more attenuated if the Council of State's advisory functions are taken into account. In comparison, American judicial review of social and economic policy-making is fairly anomalous. The importance of extensive procedure and justification, mostly in the administrative process, is unusual when set against judicial review in Germany and France.

The similarities and differences in law revealed by the functional method can also have significant theoretical payoffs. In the social sciences, there is a long tradition of comparative historical analysis and theory building on the state. ${ }^{71}$ The comparative exercise demonstrates a significant difference in the organization of state power, the requirements of the administrative and legislative process, and the relationship between judicial, political, and administrative actors. While the

70. Francesca Bignami, "From Expert Administration to Accountability Network: A New Paradigm for Comparative Administrative Law” (2011) 59:4 Am J Comp L 859; Francesca Bignami, "Comparative Administrative Law" in Mauro Bussani \& Ugo Mattei, eds, The Cambridge Companion to Comparative Law (Cambridge: Cambridge University Press, 2012) 145; Francesca Bignami, "Regulation and the Courts: Judicial Review in Comparative Perspective" in Bignami \& Zaring, supra note 38, ch 10.

71. See e.g. Theda Skocpol \& Margaret Somers, "The Uses of Comparative History in Macrosocial Inquiry” (1980) 22:2 Comp Stud Soc'y \& Hist 174; James Mahoney \& Dietrich Rueschemeyer, eds, Comparative Historical Analysis in the Social Sciences (Cambridge: Cambridge University Press, 2002); Giovanni Capoccia \& Daniel Ziblatt, "The Historical Turn in Democratization Studies: A New Research Agenda for Europe and Beyond” (2010) 43:8-9 Comp Pol Stud 931. 
public law that polices social and economic policy-making in the United States requires comprehensive procedural rationality in administrative bodies, the same public law in France and Germany demands respect for fundamental economic and social rights in the political and administrative branches. This difference is somewhat counterintuitive in light of what is generally known about the state in Europe and the United States. Individual liberty, especially economic liberty, and small government are believed to be foundational to the American state whereas extensive state authority at the expense of liberty is thought to be acceptable to Europeans. ${ }^{72}$ The rich set of observations afforded by the historical experience of the three countries can suggest explanations for why this variation is observed and contribute to theory building on the evolution of the state, the role of courts, and public law more broadly in the politics of contemporary democracies.

One possible explanation rests in the experience of judicial review and the strategic interaction between courts, elected bodies, and the administration in the early days of the policy-making of the contemporary state. In the United States, the early twentieth century was marked by a weak central bureaucracy and executive branch, strong courts, and an established tradition of elections and legislatures. In the absence of a strong state, the operation of the new administrative bodies created to manage social and economic policy-making was modelled on the adversarial (and procedural) paradigm typical of common law courts. ${ }^{73}$ Moreover, faced with strong opposition from the elected branches after Lochner $v$ New York ${ }^{74}$ the US Supreme Court repudiated economic liberties and substantive due process, and rather adopted a theory of constitutional rights and judicial review as a handmaiden of the electoral process and democracy. As is well known, in US $v$ Carolene Products, ${ }^{75}$ the US Supreme Court said that it would generally scrutinize legislation on the basis of three types of rights: those specifically articulated in the constitutional text, those related to the functioning of the democratic process, and those designed to protect minorities in the democratic process. This constitutional philosophy has carried over to administrative law: The proceduralized rationality review that emerged in the 1960s and 1970s was explained by courts and commentators as a device for

72. See e.g. Jeremy Rifkin, The European Dream: How Europe's Vision of the Future is Quietly Eclipsing the American Dream (Cambridge: Polity, 2004); Claus Offe, Reflections on America: Tocqueville, Weber, and Adorno in the United States, translated by P Camiller (Cambridge: Polity, 2005).

73. See Reuel Schiller, "The Historical Origins of American Regulatory Exceptionalism" in Bignami \& Zaring, supra note 38, ch 1.

74. 198 US 45, 25 S Ct 539 (1905).

75. 304 US 144, 58 S Ct 778 (1938). 
ensuring that the administrative process mirrored the pluralistic democratic process and for guaranteeing that the legislative imperatives contained in statute were fully executed by the administration. ${ }^{76}$

In Europe, the experience of courts, administration, and elected bodies at roughly the same historical moment was very different. In both France and Germany, a strong centrally organized bureaucracy was a feature of the nineteenth-century state and took over the administration of the social and economic policies of the twentieth-century state. Democratization (i.e., elections based on universal suffrage and democratic legislatures) came gradually and relatively late, in the late nineteenth and early twentieth centuries. The experience with democratic politics, moreover, was not a happy one: As mass democracy in the inter-war years demonstrated, elections and parliamentary regimes could give rise to immense instability and could make way for authoritarian regimes, established not by military coups, but by formally democratic procedures that put into place dictators and that abolished the political freedoms of the earlier democratic regimes. ${ }^{77}$ Public law courts, by contrast, were largely absent from the political landscape and therefore remained relatively untainted by the inter-war years: The powers of administrative courts were fairly limited, while constitutional courts did not exist. After World War II, when the new institutional architecture was put into place, constitutional courts and newly invigorated administrative courts were invested with considerable authority and entrusted with the special function of protecting basic rights against all branches of government.

As this brief comparative historical analysis suggests, public law courts in both Europe and the United States are strong, but they face different types of institutional competitors in the broader arena of democratic politics. In the United States, their major rivals for legitimate political authority are the directly elected political branches, in particular the legislature. In the French and German systems, courts compete more with the executive and with administrative bodies for legitimacy, less with the institutions of ballot-box democracy. Understanding these institutional configurations, together with the interaction among institutions at key moments in the development of the administrative state, can

76. See e.g. Harold Leventhal, "Environmental Decisionmaking and the Role of the Courts" (1974) 122:3 U Penn L Rev 509; Richard B Stewart, "The Reformation of American Administrative Law" (1975) 88:8 Harv L Rev 1669.

77. Juan J Linz \& Alfred Stepan, The Breakdown of Democratic Regimes: Europe (Baltimore: John Hopkins Press, 1978); Giovanni Capoccia, Defending Democracy: Reactions to Extremism in Interwar Europe (Baltimore: John Hopkins University Press, 2005). 
go a long way to understanding contemporary public law and how judicial review today sets the stage for political and social contestation over public policy.

Another line of inquiry suggested by this functional comparative law is more directly policy oriented: How should courts review social and economic policy-making and what are the relative merits and demerits of procedural rationality as compared to fundamental rights review? This is a question that affects not only the three countries under consideration, where law and courts may very well be so entrenched as to defy any attempts at reform, but also other jurisdictions worldwide where judicial review is a more recent development. In attempting to evaluate the two forms of review, quantitative and qualitative empirical research on whether and how they impact policy outcomes may very well be necessary. Although designing such research is challenging, there are American studies on judicial review of regulatory policy-making, and there is no reason in principle why such studies cannot also include a comparative dimension. ${ }^{78}$

In an influential line of scholarship on "adversarial legalism," American courts have been portrayed as exceptionally powerful in the regulatory process as compared with European courts: More legal challenges are brought before courts, and courts are more activist in striking government policies. ${ }^{79}$ Does procedural as opposed to rights-based review contribute to this outcome? If so, the result would be somewhat counterintuitive. The broad reach of economic rights (which in the German case cover both legislative and administrative acts) and the balancing component of most of the doctrinal tests would suggest that German (and to a lesser extent French) courts have more license than American courts to interfere with the regulatory process. It may therefore be worthwhile to revisit some of the empirical claims of the adversarial legalism hypothesis, ${ }^{80}$ which are based largely on the law as it stood in the 1980s and early 1990s, and, on the European side, on a subset of jurisdictions (mostly the UK, the Netherlands, Sweden, and Denmark). If, however, American courts continue to be more willing to strike social and economic policy-making than European courts, as some of the anecdotal evidence suggests, then it is plausible to suggest a relationship between the doctrinal theory and levels of litigant and court activism. It may be

78. See e.g. Peter H Schuck \& E Donald Elliott, "To the Chevron Station: An Empirical Study of Federal Administrative Law" (1990) 1990 Duke LJ 984; Thomas J Miles \& Cass R Sunstein, "Do Judges Make Regulatory Policy? An Empirical Investigation of Chevron" (2006) 73:3 U Chicago L Rev 823; David Zaring, "Reasonable Agencies" (2010) 96:1 Va L Rev 135.

79. Robert A Kagan, "Should Europe Worry About Adversarial Legalism?” (1997) 17:2 Oxford J Legal Stud 165; Robert A Kagan, Adversarial Legalism: The American Way of Law (Cambridge, Mass: Harvard University Press, 2001).

80. Ibid. 
that the requirements of full public participation in the administrative process, comprehensive evidence-gathering, and analytical reasoning in line with a close reading of the statutory framework are more burdensome than fundamental rights review and the rough balancing of proportionality. To understand the relationship between the doctrinal tests, levels of judicial activism, and policy outcomes, it will be necessary to conduct carefully designed comparisons of specific policy areas that take into account both constitutional and administrative law, and that examine data that are recent enough to capture the growing importance of public law litigation in Europe.

\section{CONCLUSION: A FUNCTIONAL AGENDA FOR EMPIRICAL RESEARCH IN COMPARATIVE CONSTITUTIONAL LAW}

The functional method represents an important alternative to the formal method currently prevalent in the field of comparative constitutional law and considerably expands the kinds of questions and theories, both causal and normative, that can be addressed through comparative research. As illustrated by the example of judicial review of social and economic policy-making in three important jurisdictions, the functional method can uncover areas in which the formal constitution does not have a monopoly on supreme law. Although constitutional law is the most important source of law in Germany, in the United States it is largely silent on this matter, while in France it competes internally with other legal sources and judicial bodies for supremacy. As a result, in the United States and France, administrative law operates as the supreme law of social and economic policy-making.

By identifying supreme law outside of the constitution, the functional method can expose empirical similarities and differences in public law that would otherwise go undetected. These observations can, in turn, fuel comparative learning across jurisdictions and different types of theory building. Two were suggested in connection with the public law of social and economic policy-making. First, the comparative historical analysis of courts suggests that institutional reputation and institutional competition in the broader arena of democratic politics can help explain the public law that today sets the stage for social and economic policy-making. Second, a comparison of the different forms of public law in operation in the three jurisdictions (procedural rationality versus fundamental economic and social rights) can inform a normative analysis of how the judiciary should intervene in government policy-making. 
The functional method can also offer a word of caution for comparative constitutional law based on the formal approach to comparative research. Comparison is an important tool for testing the causes and consequences of law because it provides the critical variation on both the law and the context of the law necessary to test hypotheses and control for alternative explanations. ${ }^{81}$ In comparative constitutional law, there are a number of ongoing empirical initiatives, generally based on quantitative methodologies, to collect the data necessary to test theories on the relationship between constitutional law and various types of social and political outcomes. ${ }^{82}$ These studies typically rely on the formal method of comparative law. The reason is clear: Since quantitative methodologies require large numbers of cases and observations, the formal label of "constitutional" document or "constitutional" court is a convenient tool of research design. ${ }^{83}$ It allows for reliable coding of the law across the broad swath of countries that today have both a constitution and a constitutional court. The difficulty, however, is that what is called constitutional law does not always indicate what is supreme law; to translate into the language of empirical methodology, it might not be a valid measure of the supreme law. In the comparative project explored in this article, constitutional law was under-inclusive: Both France and the United States operate with higher law that disciplines social and economic policy-making, but that is called "administrative," not "constitutional." In other areas of social and political life or in other jurisdictions, constitutional law may be over-inclusive: The guarantees contained in the constitutional document or pronounced by the constitutional court may not operate as supreme law in the life of the polity.

The mismatch between formal and functional constitutional law requires that comparative researchers think long and hard before they use large- $\mathrm{N}$ data sets that rely, implicitly or explicitly, on the formal method. For certain types of questions and theories, the formal approach to research design might indeed be

81. See generally Holger Spamann, "Empirical Comparative Law" (2015) 11 Ann Rev L \& Soc Sci 131.

82. See Comparative Constitutions Project, "Informing constitutional design" (2016), online: $<$ www.comparativeconstitutionsproject.org >; Toronto Initiative for Economic and Social Rights, (2010), online: <www.tiesr.org>; Clifford J Carrubba et al, An Introduction to the CompLaw Database (5 April 2013), online: <polisci.emory.edu/faculty/jkstato/resources/ WorkingPapers/complaw2.pdf>; Doron Shulztiner \& Guy Carmi, "Human Dignity in National Constitutions: Functions, Promises, and Dangers” (2014) 62:2 Am J Comp L 461.

83. See generally Gary King, Robert O Keohane \& Sidney Verba, Designing Social Inquiry: Scientific Inference in Qualitative Research (Princeton: Princeton University Press, $1994)$ at $25-26$. 
appropriate. These are theories that rest on properties of constitutions other than that of supreme law, for instance, the polity-building role of constitutions or the signal conveyed by constitutions to the broader international community. But for questions and theories that rest on the status of constitutional law as the supreme law of a jurisdiction, a research design built on a formal approach to constitutional law-one that assumes equivalence between what is formally called constitutional law and the supreme law-will often be the wrong design. Of course, it might be that in some areas of political and social life, what is functionally the supreme law (to the extent that there is supreme law on the subject) is universally set down in the formal constitution. In such cases, formal constitutional law is indeed a good indicator of functional constitutional law and it might be possible use the large- $\mathrm{N}$ data sets. The kind of comparative legal knowledge necessary to substantiate such an assumption, however, is considerable even with respect to a handful of countries. To address the problem, efforts at data collection should be based on a more extensive knowledge of the law on the ground in each of the country cases. This coding strategy would contribute to more valid measurement of what is supreme law across different areas of social and political activity and could fuel a broad range of research projects in comparative constitutional law. 